\title{
A Conceptual Smart City Framework for Future Industrial City in Indonesia
}

\author{
Julius Galih Prima Negara ${ }^{1}$, Andi W. R. Emanuel ${ }^{2 *}$ \\ Magister Teknik Informatika, Universitas Atma Jaya Yogyakarta \\ Sleman, Indonesia
}

\begin{abstract}
In Indonesia, the growth of cities from various big cities and industrial cities can cause many challenges. To face this challenge, policy makers can apply the concept of smart cities. This paper aims to analyze many studies that discuss prospective industrial city planning in a smart city perspective. This research uses information from research, models, frameworks, and tools that discuss IoT, smart cities, and industrial cities. This research provides the latest insight into smart city frameworks for industrial cities. In this study found the pillars forming the smart city for industrial cities. This framework can also be used by governments such as Kulonprogo District in the Special Region of Yogyakarta, Indonesia in preparation to transform itself into a smart industrial city. The latest use of information technology in this concept and with implementation priority steps is recommended.
\end{abstract}

Keywords-Smart city; industrial city; smart industrial city; framework; Kulonprogo District

\section{INTRODUCTION}

Cities are complex systems that are characterized by massive numbers of interconnected citizens, businesses, different modes of transportations, communication networks, services and utilities [1]. These cities face many challenges during their development and smart city is believed to be the answer to these challenges. Connecting many residents linking smart transportation needs, facilitating communication, improving government performance, and making some aspects of people's lives "smart" are the embodiment of a smart city. Many cities in Indonesia also face similar challenges.

The development of the cities in Indonesia is very dynamics due to their own unique characteristics. The capital city such as Jakarta is inhabited by government officials, national and multi-national company workers, and travelers. Tourism cities such as Denpasar in Bali, besides being inhabited by indigenous people, are also visited by domestic and foreign tourists. The city of education, such as Yogyakarta is inhabited by visitors who study and they leave when they finish their study. There are also several industrial cities such as Karawang, Surabaya, Cilegon, etc. These industrial cities are existed and developed due to manufacturing industries, and they will eventually become larger industrial cities.

Industries have big impacts for the surrounding environment, especially for the cities in which they reside. Policy makers must prepare an industrial city that cares about the environment, saves electricity, and minimizes the role of workers by optimizing technology. The government must prepare for the arrival of migrants from other cities who work and live in city. Even though this is a busy city with high mobility of the people, local government must have obligations to improve the quality of life of the citizens.

This research is looking for the right framework for cities that are prepared to become industrial cities, and what elements must be met to realize the concept of smart city in an industrial city. As a limitation, this study discusses the appropriate framework for realizing Kulonprogo District as a smart industrial city. Kulonprogo District (kulonprogokab.go.id) is located in western part of the Special Region of Yogyakarta, Indonesia. In the literature review section, the author provides information relating to industrial cities, smart cities, and the application of smart city concepts in industrial cities. Next in this paper will be discussed about smart city architecture and priorities for implementing smart city policies in Kulonprogo as potential industrial cities.

\section{LITERATURE REVIEW}

\section{A. Industrial City}

According to the KBBI (Kamus Besar Bahasa Indonesia), an industrial city is a city that is a place of residents who are mostly involved in industrial activities. Therefore, there are aspects of communication and cooperation between all the people within the city. The government, government-owned companies, private companies, investors, workers are stakeholders who are actively involved in urban activities. To support the process of city activities, the industry's main supporting infrastructure must be prepared. The government prepares the city vision, regulations, physical infrastructures, and creates favorable investment climate. When there is a clear vision, legal certainty, well-prepared physical infrastructures, the investment climate will grow significantly in which investors will come to invest. The use of the latest technology for the development of industrial cities is also important to improve the quality and quantity of production.

In the last few years a concept of Industry 4.0 has developed. This concept holds the promise of increased flexibility, mass customization, increased speed, improved quality, and enhanced productivity in manufacturing and thus enabling companies with various challenges, such as increasingly individualized products, shortened leads time to market, and high product quality [2]. The eight planning to enable the concept are: standardization of systems and building a references architecture; efficient management, establishment a comprehensive and reliable industrial

\footnotetext{
*Corresponding Authors
} 
broadband infrastructure; safety and security, organization and design of works; staff training and continuing professional development; establishing a regulatory framework in improving of the efficiency of resource use.

\section{B. Smart City}

There are many interpretations of smart city by researchers, and they mostly focus on three interpretations. Table I shows some papers with their interpretations of smart city.

Table I shows several studies regarding three differences in the focus of smart city. The first focus is smart city which emphasizes the best and latest technology to be applied to a city. The second focus is the population who are already aware of the use of technology, so they design a city by placing technology to help solve their problems. The third focus is the combination of the previous focuses, which are technological advancements are complementary to the desires of city residents in creating a smart city.

\section{Smart City Characteristics}

There are four smart city components, namely: smart infrastructure, smart operations, smart services and smart industries. Moreover, smart city has four basic characteristics [8]:

- Interconnection between parties in the city: smart cities will integrate means of communication, sensors, internet and support to facilitate, accelerate communication without obstacles [9][10].

- Integration of urban information systems: The Internet and cloud computing are used in all aspects of city life.

- Management of government services and urban services to provide the best service.

- Technology applications, especially the latest ICT: smart cities use modern city management as a guide, emphasizing the application of information technology into city management and inspiring all government agencies, companies, and people to make innovations, urban development movements

TABLE I. SMART CitIES DEFINITION

\begin{tabular}{|l|l|l|}
\hline $\begin{array}{l}\text { Smart City } \\
\text { interpretations }\end{array}$ & Focus & Reference \\
\hline $\begin{array}{l}\text { Best and modern } \\
\text { technology to be } \\
\text { applied in the city }\end{array}$ & Smart City focusing on technology. & {$[3][4]$} \\
\hline $\begin{array}{l}\text { City with a lot of } \\
\text { people with a lot of } \\
\text { challenges } \\
\text { to solved }\end{array}$ & $\begin{array}{l}\text { Smart City focusing on human } \\
\text { resources }\end{array}$ & {$[5][6]$} \\
\hline $\begin{array}{l}\text { Smarter collaboration } \\
\text { in the city }\end{array}$ & $\begin{array}{l}\text { Smart City focusing on governance } \\
\text { and managerial }\end{array}$ & {$[7][8][9]$} \\
\hline
\end{tabular}

\section{Characteristic of a Smart city in Industrial City}

Based on the references in this study by integrating the concept of smart city into industrial city, the categorization of smart city characteristics for industrial cities are:

- Emphasizing on support for factory production process activities

- Using the latest technology for communication between parties in the industrial process. Examples of the use of communication technology are the construction of an LTE/4G or upcoming $5 \mathrm{G}$ backbone line between sub-districts and connecting between government, companies, investors, and urban communities.

- Using the IoT mindset in everything. IoT allows multiple parties to share data and information.

- Realizing environmental awareness by preparing waste treatment and using energy efficiently.

- Preparing smart transportation facilities, and transportation infrastructure that allows connections between cities, ports, international airports, train stations, bus terminals are some of the facilities that must be prepared. Industrial workers need efficient transportation facilities to support their mobility.

- Implementing smart education is to help the industry to meet their needs for the workforce according to their needs. Even though technology has helped many industrial activities and has begun to reduce the role of humans, the government must also prepare a qualified workforce.

\section{E. Pillars of Smart City}

There are several things that must be prepared in order to realize smart city into industrial city. The preparation starts from citizen involvement to investment. There are several pillars of smart city development and four main development pillars [11] which is possible by the concept of IoT as shown in Fig. 1.

Fig. 1 shows that primary aspect that is required is the involvement of all parties. The government and the whole community must have the will to be involved. After that there are four main pillars: Institutional Infrastructure, Physical Infrastructure, Social Infrastructure and Economic Infrastructure. After the four pillars of development are accomplished, the next is the procurement of technology. The technology that is realized must have flexibility and sustainability. As a result, employment opportunities and quality of life for urban communities will increase. As a result, the possibility of investment will open to the city, and skills from the community will eventually be improved.

Fig. 2 below is a description of smart city composition architecture. 


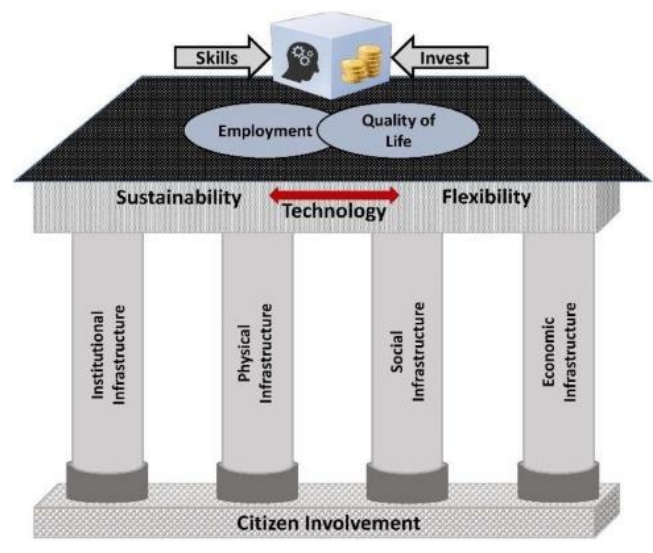

Fig. 1. Smart City's Pillars [11].

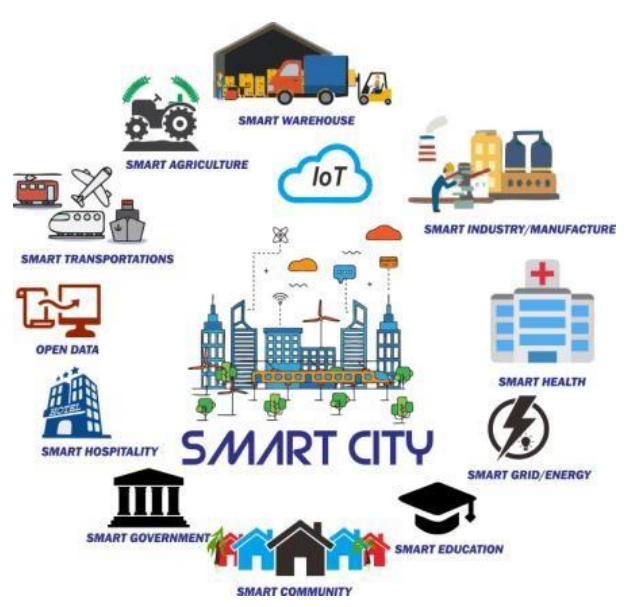

Fig. 2. Smart City Composition Architecture.

As shown in Fig. 2, smart city has supporting architectural components that can make a city become a smart city. The supporting component for the realization of smart city in a city that is prepared to become an industrial city are: smart warehouse, smart industry, smart healthcare, smart grid / energy, smart education, smart community, smart government, smart hospitality, open data, smart transportation, and smart agriculture.

\section{SMART CITY FFR FUTURE INDUSTRIAL City}

The smart city can be interpreted as using the latest technology to make other fields smart. Smart city allows connectivity between many fields in a city. Communities and governments also communicate and exchange data because of an open data concept. The following are the smart city composition architecture.

\section{A. Smart Warehouse}

In supporting industrial process, the smart warehouse becomes a necessity. The company product needs to be arranged in order to facilitate data collection and distribution process. The company also requires a qualified security system. Policy makers can see this as an opportunity. The first in first out process is arranged perfectly so that the age of the products produced is in accordance with what is predicted, and the consumer receives the new product accordingly. From the entrepreneur's side, they also need security of their products before being distributed. Technology plays an important role in the development of this smart warehouse.

\section{B. Smart Industry}

Smart industries should have concern for the environment by doing effective waste treatment and efficient use of energy sources [10][12]. We can interpret smart industry is an industry that is oriented to high quality and quantity of production by utilizing the latest technology, communication, automation, artificial intelligence, and mechatronic technology.

\section{Smart Healthcare}

There are several researches consider the smart health as one of smart city architectural component [10][13]. Smart health can utilize technology and process that help the citizen to get better life. The level of population growth in the city brings several challenges and obstacles to solve in the health sector. Therefore, traditional and conventional health services are no longer enough and are expected to continue to be obsolete if not improved. Physical infrastructure in the health sector must be improved, especially those using the latest technology to solve problems in handling speed, accuracy, and quantity of services. Health facilities must improve patient examination services, improve the quality of drug services, and reduce the impact of disease transmission. Currently, there are still gaps between the expectations from the government, the community, and in reality. Information technology has a great opportunity to help solve these health challenges [11].

\section{Smart Grid/Energy}

Energy management is one of main concern for the government. Saving and providing energy for future generations is a challenge. The energy-saving culture must be continually promoted. Then comes the concept of intelligent energy that comes with technological innovations to help make energy savings and use of renewable energy. More holistic approaches must be utilized to focus on renewable, sustainable and green energy [11]. The saving of nonrenewable resources for utilization in high priority matters is the main objective of smart energy [9]. The government with smart city governance should care about the environment.

\section{E. Smart Education}

To fulfill human resources in industrial cities, an education system can be developed that produces graduates who are in accordance with the needs of the industry. If local education in the city produces graduates who have enough qualifications, it will suppress the arrival of new residents from outside the city. Improving the quality of education by utilizing technology is considered to be the answer [14].

\section{F. Smart Community}

Smart community is aimed to give more satisfaction to the citizen in the city. Giving effective and efficient government services in using technology is the goal of community satisfaction. Community needs that have been fulfilled will have an impact on the quality of life and public trust in the ruling government [11]. This section will connect several sectors of community needs in waste management, smart building governance, intelligent water management, etc. 


\section{G. Smart Government}

The concept of smart government is the use of technology to assist the government in managing administration and serving the community. With Smart government, the government is fundamentally transformed into a time-efficient organization, high in performance results, and opened from the information side. Government policies become something more valuable and accountable. Community and company licensing processes are easier, cheaper and timely manner [15].

\section{H. Smart Hospitality}

One of the targets of the government is to make the city an attractive investment area. The government must welcome anyone visiting the area who may become the prospectus investors. Investors will be very happy if they get a prompt response when it comes to investment destinations. The smart city concept will handle the creation of this smart hospitality service easily [1][16].

\section{Open Data}

In a smart city, data is something that is the object that is sought by its citizens. Openness is needed so that the whole community can access information according to their respective privileges. For example, the community needs population data to be used as a condition for managing education, marriage, and even taking care of health insurance or insurance. Another example the government can announce the opening of an auction or the announcement of a government project auction. The government should open data as much as possible as long as it is permitted by regulation [17].

\section{J. Smart Transportation}

The government must prepare effective public transportation facilities to facilitate the high mobility of its citizen. Effective transportation can be described as a means of transportation that guarantees the mobility of citizens in a timely manner, information on transportation facilities that are easily available, safe, and there are various types of transportation to choose from. The government must prepare transportation facilities that are in accordance with the area [13][14][18]. Presenting inter-district bus transportation or working with industry to present buses as a means of transportation for employees to leave and return to work at the factory. The government can provide a means of transportation that allows for in and out access between cities and even between countries, for example:

- Light Rail Transit that connects trains with the surrounding city / district as a buffer for the city.

- International Airports that can be the gateway for people going and coming in the city.

- International Port that can be a means of supporting in and out of export and import of manufactured products as well as raw materials.

\section{K. Smart Agriculture}

In supporting a city as an industrial city, agriculture can be used as a support for the basic needs of the factory, and the food needs of the community. Increasing agricultural yields is a necessity when industry becomes a label for a city. This is because the population will automatically increase and need more food sources. Then if from the world of industry, the industrial staples should be sustained by the region itself because it will reduce transportation costs [19]. In its implementation we can use the Industry 4.0 scheme. This concept is possible to be applied to an industrial city designed as a smart city. As the first step is to build networks, second is research on two major themes related to industrial technology, and finally is to realize the integration. Smart factory and intelligent production are the big theme. The integrations are: horizontal, vertical, and end-to-end [2].

\section{Priority Steps to Enable}

By observing the current conditions, the Kulonprogo District government as one of the districts that want to become an industrial city should prepare many aspects. There are 4 recommended priority steps to enable smart city in future industrial city for Kulonprogo District as shown in Fig. 3.

- First step is increased shared awareness between the government and the community. The government with its political steps can create legal rules as a rule for implementing smart city. The public must be aware that technology plays an important role in improving the quality of life.

- Second step is to prepare the four pillars needed for smart cities [7][11] as shown in Fig. 1. The four pillars of the infrastructure must be prepared to become a solid foundation for the future development.

- The third step is mapping the appropriate technology needs for the city. The aim of this step is to avoid the procurement of inappropriate technology.

- The fourth step is investment. This investment in smart city can be interpreted as two types of investment: investments from the government as an organizer, and private sector investment. Investment from the government is a must. Investment from the private sector becomes support so that the project gets significantly improved. For example, when the government will build a LTE/4G or $5 \mathrm{G}$ communication network, the government can use the private sector to help build this communication facility [20][21]. Then the next example is calling on investors from waste treatment companies to manage municipal and industrial waste so that cities become environmentally friendly cities.

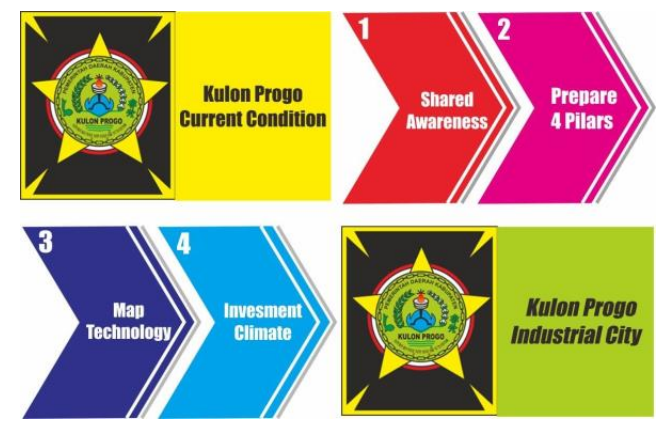

Fig. 3. Smart City Priority Steps for Kulonprogo District. 


\section{CONCLUSION}

In this paper, the view of the concept of smart cities to be applied in the industrial city initiative is proposed. Even though both have some differences, they can support each other in the development of an area that is used as an industrial city. This paper provides information about what the smart city architecture is for industrial cities, and what steps to take. A look at Industry 4.0 factories as smart city building blocks is proposed, among other architectural components such as smart health care, smart community, smart education and many more. Both concepts are based mainly on the Internet of Things and Internet which allows saving energy connecting and empowering humans.

Industry has always been an important part of the overall concept of the city and cannot be seen separately. Linking individual components can be expected through IoT. There are 10 parts to this concept: Smart Warehouse, Smart Industry, Smart Healthcare, Smart Grid/Energy, Smart Educations, Smart Community, Smart Government, Smart Hospitality, Open Data, Smart Transportations, and Smart Agriculture. The Kulonprogo District has had big dreams for the future of a city to become smart industrial city in which open data and smart governance have been initialized. This research can be continued with the application of the concepts.

It is necessary to do a research on whether the smart city development scheme for industrial city is appropriate or requires improvement. This work can be considered as a preliminary contribution to the development of empirical research in order to obtain a better understanding this smart city concept for industrial city.

\section{REFERENCES}

[1] P. Neirotti, A. De Marco, A. C. Cagliano, G. Mangano, and F. Scorrano, "Current trends in smart city initiatives: Some stylised facts," Cities, vol. 38, pp. 25-36, 2014.

[2] Z. Keliang, "Industry 4.0 Towards Future Industrial.pdf."

[3] T. hoon Kim, C. Ramos, and S. Mohammed, "Smart City and IoT," Futur. Gener. Comput. Syst., vol. 76, no. July 2014, pp. 159-162, 2017.

[4] M. M. Rathore, A. Paul, W. H. Hong, H. C. Seo, I. Awan, and S. Saeed, "Exploiting IoT and big data analytics: Defining Smart Digital City using real-time urban data," Sustain. Cities Soc., vol. 40, pp. 600-610, 2018.

[5] M. Eremia, L. Toma, and M. Sanduleac, "The Smart City Concept in the 21st Century,” Procedia Eng., vol. 181, pp. 12-19, 2017.
[6] U. Aguilera, O. Peña, O. Belmonte, and D. López-de-Ipiña, “Citizencentric data services for smarter cities," Futur. Gener. Comput. Syst., vol. 76, pp. 234-247, 2017.

[7] R. K. R. Kummitha and N. Crutzen, "How do we understand smart cities? An evolutionary perspective," Cities, vol. 67, no. July 2016, pp. 43-52, 2017.

[8] B. S. P. Mohanty, U. Choppali, and E. Kougianos, "Everything You Wanted to Know About Smart Cities,” no. JULY 2016, p. 70, 2016.

[9] N. C. Batista, R. Melício, and V. M. F. Mendes, "Services enabler architecture for smart grid and smart living services providers under industry 4.0," Energy Build., vol. 141, pp. 16-27, 2017.

[10] B. Chen, J. Wan, L. Shu, P. Li, M. Mukherjee, and B. Yin, "Smart Factory of Industry 4.0: Key Technologies, Application Case, and Challenges," IEEE Access, vol. 6, pp. 6505-6519, 2017.

[11] B. N. Silva, M. Khan, and K. Han, "Towards sustainable smart cities: A review of trends, architectures, components, and open challenges in smart cities," Sustain. Cities Soc., vol. 38, no. January, pp. 697-713, 2018.

[12] P. Zheng et al., "Smart manufacturing systems for Industry 4.0: Conceptual framework, scenarios, and future perspectives," Front. Mech. Eng., vol. 13, no. 2, pp. 137-150, 2018.

[13] R. Khan, S. U. Khan, R. Zaheer, and S. Khan, "Future internet: The internet of things architecture, possible applications and key challenges," Proc. - 10th Int. Conf. Front. Inf. Technol. FIT 2012, pp. 257-260, 2012.

[14] M. Abdel-Basset, G. Manogaran, and M. Mohamed, "Internet of Things (IoT) and its impact on supply chain: A framework for building smart, secure and efficient systems," Futur. Gener. Comput. Syst., vol. 86, pp. 614-628, 2018.

[15] A. Meijer and M. P. R. Bolívar, "Governing the smart city: a review of the literature on smart urban governance," Int. Rev. Adm. Sci., vol. 82, no. 2, pp. 392-408, 2016.

[16] C. Lim, K. J. Kim, and P. P. Maglio, "Smart cities with big data: Reference models, challenges, and considerations," Cities, vol. 82, no. August 2017, pp. 86-99, 2018.

[17] L. Anthopoulos, "Smart utopia VS smart reality: Learning by experience from 10 smart city cases," Cities, vol. 63, pp. 128-148, 2017.

[18] L. Hao, X. Lei, Z. Yan, and C. L. Yang, "The application and implementation research of smart city in China," Proc. 2012 Int. Conf. Syst. Sci. Eng. ICSSE 2012, no. 70172014, pp. 288-292, 2012.

[19] N. Mccarthy, "Climate Smart Agriculture: A Synthesis of Empirical Evidence of Food Security and Mitigation Benefits from Improved Cropland Management Climate Smart Agriculture: A Synthesis of Empirical Evidence of Food Security and Mitigation Benefits from Improved C," no. December 2014, 2011.

[20] Z. Michele, "Internet of Things for Smart Cities," IEEE Internet Things J., vol. 1, no. 1, p. 22, 2014.

[21] A. Gaur, B. Scotney, G. Parr, and S. McClean, "Smart city architecture and its applications based on IoT," Procedia Comput. Sci., vol. 52, no. 1, pp. 1089-1094, 2015. 